\title{
Academic nursing educators and students perception of institutional quality
}

\author{
Rabaa A. Mohamed ${ }^{1}$, Ebtsam Aly Abou Hashish ${ }^{* 2}$, Gehan G. El-Bialy ${ }^{2}$ \\ ${ }^{1}$ Quality Assurance Unit, Faculty of Nursing, Alexandria University, Alexandria, Egypt \\ ${ }^{2}$ Nursing Administration Department, Faculty of nursing, Alexandria university, Alexandria, Egypt
}

Received: July 28, 2015

Accepted: September 8, $2015 \quad$ Online Published: September 28, 2015

DOI: $10.5430 /$ jnep.v5n12p111

URL: http://dx.doi.org/10.5430/jnep.v5n12p111

\begin{abstract}
Background: Today, educational institutions are compelled to deliver quality service to their consumers to survive in competitive educational markets. Investigating educators' and students' perception and satisfaction with the institutional quality is significant to judge whether they had what they expected or not. Also, creating meaningful changes in universities or colleges, needs that educational leaders should attempt to analyze and interpret various consumers' opinions to improve the needed dimensions of educational quality. This study aims to investigate the perception of nursing educators and students of the institutional quality of Faculty of Nursing, Alexandria University.

Methods: A comparative descriptive research design was conducted at the Faculty of Nursing, Alexandria University. Higher Education Institution Accreditation Questionnaire was given to 230 nursing educators and 450 nursing students to investigate their perception of the institutional quality.

Results: The current study revealed that, institutional quality of the Faculty of Nursing was rated as moderate by both nursing educators and students. However, nursing educators and students different significantly in their overall ratings of institutional quality $(t=8.460, p \leq .001)$ and its dimensions, including input $(t=7.856, p \leq .001)$, process $(t=9.535, p \leq .001)$ and output $(t$ $=5.356, p \leq .001)$. Faculty mission and purpose, teaching staff quality, excellence of facilities and resources and job expectation were the most prominent factors of institutional quality as perceived by nursing educators and students. In addition, perception of institutional quality also, affected by factors such as academic department, position, semester and participation in quality improvement-related activities.

Conclusions: Positive institutional quality relates to a positive perception of both nursing educators and students of institutional quality. Various factors that affect consumers' perception and satisfaction of institutional quality should be considered and controlled by academic leaders in order to increase satisfaction and meeting consumers' expectations. Different strategies should be implemented to continue improvement of institutional quality of the Faculty of Nursing through enhancing a quality teaching framework which allows the institution to monitor, support, track nursing educators' and students' satisfaction, and study its impact on the teaching-learning process. Although perception of educators and students are important, institutional quality is more than what they perceive specific in a program like nursing. Further research study should examine other factors considered significant in determining institutional quality such as hiring rates, stakeholders and employers' satisfaction with nursing graduates.
\end{abstract}

Key Words: Institutional quality, Higher education institution accreditation, Nursing educators, Students

${ }^{*}$ Correspondence: Ebtsam Aly Abou hashish; Email: ebtsam_ss@ hotmail.com; Address: Nursing Administration Department, Faculty of nursing, Alexandria university, Alexandria, Egypt.

Published by Sciedu Press 


\section{INTRODUCTION}

The interest in the quality of the educational services provided by academic institutions grew over the last decade. Academic institutions are striving to provide and place great emphasis on meeting students' expectations and needs to be identified with institutional quality, develop and maintain their reputation. ${ }^{[1,2]}$ Educational managers are challenged to create and sustain internal systems and control to implement quality-focused strategies in their faculties/colleges. ${ }^{[3,4]}$ Quality in higher educational institution is a multi-dimensional, multi-level, and dynamic concept that relates to the context setting of an educational model, the institutional mission and objectives, and specific standards within a system, institution, program, or discipline. ${ }^{[5]}$ Institutional quality is defined as judgment about overall excellence or superiority of an entity. It is an attitude and a degree of satisfaction, resulting from a comparison of expectations with the perception of performance. ${ }^{[6]}$ In the quality approach, an effective educational organization requires sound internal structure and processes to demonstrate sustained quality services for its consumers over times. It may implement assessment and evaluation mechanisms to identify and promote good teaching practices. Quality assessment of educational institutions becomes essential because it examines a wide range of influences that shape the learning experiences and achievements of students. ${ }^{[5,6]}$

\subsection{Study framework}

In 2001, Yoo developed a conceptual framework for assessing and judging quality dimensions in higher education based on Donabedian approach to assess quality which considered the first framework for organizing quality assessment and illustrated the link between process and outcome approaches. It is based on a study of possible interpretations of quality dimensions and reviewing quality factors proposed for higher education. The framework of Yoo (2001) which used in the current study comprises three dimensions; input, process and output dimensions. Input dimension, represents the plausible factors that cause academic and career development of the educators and students. It includes the perception of quality indicators such as: program mission and purpose, facilities and resources, academic teaching staff quality, instructional material, student service-governance and administration, financial resources, institutional reputation and climate.

Process dimension, is the second point in the quality framework which screen all content that institution can provide to the students whether in teaching and learning, the lecturers' knowledge ability, the curriculum and assessment. Judgement and evaluation of process dimension can be reflected in meeting educators' and students' job expectations and academic development factors. Job expectations measure the degree to which students get a job easily after graduation, and the degree to which the faculty/college has a large job market place, and provide multiple work areas for graduates. Academic development measures the degree of satisfaction with quality of teaching content, understanding and learning of knowledge gaining skill, provision of updating curriculum design and the theoretical studies with integration of practical skill.

Output dimension, refers to the overall satisfaction with the faculty/college quality and the degree to which academic educators and students feel that their faculty/college is valuable for them in their life. Output dimension measures the degree to which nursing educators and students perceive; they can recommend the faculty/college to other persons, the faculty/college has a clear vision, and considered as a stepping - to scientific and working life, learning costs and time are valuable, and choice of the faculty/college was successful. ${ }^{[6]}$

\subsection{Significance of the study}

Any attempt to measure university/faculty/college quality should take into account all consumers' perspectives. ${ }^{[7]}$ Consumers such as educators/teachers and students are the most significant ones because they can provide constructive judgment and deciding if the quality needs more evaluation and improvement. ${ }^{[8]}$ The expectations of nursing educators are valuable like students' expectations of institutional quality. Also, assessing students' satisfaction with institutional quality of their college/faculty is significant to judge whether they had what they expected or not. In addition, creating meaningful changes in universities, needs that educational leaders should attempt to analyze and interpret various opinions of the nursing educators to improve the needed dimensions of educational quality. ${ }^{[6,8]}$

Studies done internationally examined the institutional effectiveness and quality of higher education, students' perceptions of service quality at their universities, students' satisfaction with faculty teaching. ${ }^{[2,6,8-12]}$ These studies highlighted the importance of evaluating institutional quality of faculties/universities from different perspectives and gather information about academic staff and students' satisfaction to determine to what extent they are satisfied with their faculty and determine the strengths and weak points within the faculty.

However, up to the knowledge of current researchers, studies in this field in Egypt have been limited to understand the complex and multidimensional nature of the quality of higher education. ${ }^{[13]}$ Another study was done to explore students' satisfaction at educational institutions. ${ }^{[14]}$ Higher education institutions need to set and evaluate their strategies accord- 
ing to students' expectations and needs not what universities want and expect and to evaluate their quality. Among all the studies that were carried out in educational quality, no attempt was done to investigate nursing educators' and students' perception of the institutional quality, especially in nursing facilities. Hence, it is hoped that such study will help the faculty's administrators and leaders with the needed information and insights to encourage and sustain improvements in the educational process and quality dimensions.

\subsection{Aim of the study}

The aim of this study was twofold to: (a) investigate nursing educators' and students' perception of the institutional quality of the Faculty of Nursing, Alexandria University, and identify what is the difference in their perception, and (b) identify what are the factors affecting nursing educators' and students' perception of the institutional quality?

\subsection{Research questions}

- How do nursing educators and students perceive the institutional quality of the Faculty of Nursing at Alexandria University?

- What is the difference in the perception of nursing educators and students regarding the institutional quality of the faculty of nursing?

- What are the factors affecting nursing educators and students' perception of the institutional quality?

\section{MATERIAL AND METHODS}

\subsection{Research design and setting}

A comparative descriptive research design was conducted at the Faculty of Nursing, Alexandria University.

Faculty of Nursing, Alexandria University is the first nationally accredited nursing institution, and the second accredited faculty at the Egyptian universities in all scientific specialties. It seeks a high level of quality in educational programs that are evaluated periodically according to the national quality standards for both baccalaureate and post-graduate programs. ${ }^{[15]}$

\subsection{Participants}

The subjects of the study comprised:

1) All nursing educators $(\mathrm{N}=230)$ who were working at the Faculty of Nursing, Alexandria University, taught nursing students and agreed to participate in this study were eligible, including: 51 Professors, 16 Assistant Professors, 43 Lecturers, 41 Assistant lecturers, 51 Demonstrators and 30 Clinical instructors.

2) A random sample of $50 \%$ of nursing students who were enrolled at all academic semesters for the academic year

Published by Sciedu Press
2012-2013 and agreed to participate in the study $(\mathrm{N}=450)$ were included, they classified into: 50 nursing students in first semester, 60 in second semester, 60 in third semester, 41 in fourth semester, 56 in fifth semester, 27 in sixth semester, 80 in seventh semester and 76 students in eighth semester.

\subsection{Study tool}

Higher Education Institution Accreditation Questionnaire (HEIAQ) developed by Yoo (2001) ${ }^{[6]}$ was used to measure perception of nursing educators and students of the institutional quality. It comprised 73 items categorized in 11 subscales namely; mission and purpose (6 items), facilities and resources (8 items), academic teaching staff quality (6 items), instruction efficiency ( 7 items), students service-governance and administration ( 7 items), financial resources ( 7 items), institutional reputation (6 items), institutional climate ( 7 items), job expectations (5 items), academic development ( 7 items) and overall satisfaction with faculty quality (7 items). The questionnaire was delivered in two forms, one for nursing educators and another one for nursing students. Responses were measured on 7 points Likert scale ranged from strongly agree (7), to strongly disagree (1). The higher response indicated higher institutional quality perceived at the Faculty of Nursing, Alexandria University.

In addition, academic and demographic form was developed by the researchers for the nursing educators and students. It included questions related to (age, sex, educational level, academic position, academic department, years of experience and participation in faculty quality improvement projects and related activities or not) for nursing educators and (age, sex, and academic semester) for nursing students.

\subsection{Validity and reliability}

The nursing students' form of the study's questionnaire was translated into Arabic and examined for translation. The two forms of the questionnaire (nursing educators and nursing students) were examined for content validity and relevance to be suited for Egyptian culture by 5 experts in the field of study from different academic departments at the Faculty of Nursing, Alexandria University. Also, a pilot study was done on $10 \%$ of nursing educators $(n=25)$ and students $(n=40)$ that were excluded from the study participants to; check and ensure clarity and applicability of the tool; identify obstacles and problems that may be encountered during data collection. Accordingly, no modification was done for the two forms of the tool. In addition, the two forms were examined for reliability to measure the internal consistency of the items using Cronbach's alpha coefficient test. The questionnaire was proved reliable where $\alpha=0.937$ for nursing educators' form, and $\alpha=0.964$ for nursing students' form. 


\subsection{Data collection}

A written approval was obtained from the dean of the Faculty of Nursing, Alexandria University to collect the data Data were collected using self-administered questionnaire which distributed individually for nursing educators in their academic departments and for nursing students during their clinical conferences and scheduled lectures at the faculty. It took a period of three months to collect data started from $1 / 11 / 2012$ to $31 / 1 / 2013$.

\subsection{Ethical considerations}

Approval was obtained from the Ethics Committee of the Faculty of Nursing, Alexandria University. The privacy and confidentiality of data were maintained and assured by getting participants' consent to participate in the research before data collection. Anonymity of participants was granted.

\subsection{Data analysis}

Percentages were used for describing demographics and academic characteristics. Arithmetic mean and standard deviation (SD) were used as measures of central tendency and dispersion, respectively, for quantifying variables under the study. Student's $t$-test was used to compare between two means, and one-way analysis of variance (ANOVA) (F) was used to compare the mean scores among more than two groups. All statistical analyses were done using 2-tailed tests and $\alpha$-error of 0.05 . $P$-value $\leq .05$ was considered to be significant.

\section{RESULTS}

\subsection{Demographic characteristics}

Nursing educators were predominately female (97\%) and were quite youthful with $41.3 \%$ being under 30 years of age. The largest proportion (46.5\%) held doctorates in nursing. About one third $(28.7 \%)$ had more than 20 years of experience and the highest proportion $(57.4 \%)$ participated in faculty quality improvement projects and related activities. They distributed across all academic departments. Similarly, nursing students were predominately female $(73.8 \%)$ and were distributed across all academic semesters. Additional information regarding the demographic characteristics of the participants can be found in Table 1 .

\subsection{Perception of the institutional quality at Faculty of Nursing, Alexandria University}

Overall and in all dimensions, institutional quality of the Faculty of Nursing was rated as moderate by both nursing educators and students, Mean \pm SD $(4.97 \pm 0.93$ and $4.25 \pm$ 1.14) respectively. However, nursing educators and students differ significantly in their overall ratings of institutional quality $(t=8.460, p \leq .001)$ and its dimensions, including input $(t=7.856, p \leq .001)$, process $(t=9.535, p \leq .001)$ and output $(t=5.356, p \leq .001)$. Regarding the perception of input dimension, nursing educators gave their highest quality ratings to "faculty mission and purpose $(5.47 \pm 1.17)$ and to faculty teaching staff quality $(5.09 \pm 1.07)$ ". While, nursing students rated "the excellence of facilities and resources $(4.50 \pm 1.32)$ and faculty mission and purpose $(4.36 \pm 1.44)$ " as the highest input factors.

On the contrary, Nursing educators gave their lowest quality rating to financial resources $(4.34 \pm 1.27)$, while nursing students gave their lowest quality rating to "student servicegovernance and administration (3.70 \pm 1.30$)$ ". In process dimension, both nursing educators and nursing students rated job expectations $(5.79 \pm 1.0,4.98 \pm 1.49)$ higher than academic development $(5.30 \pm 1.11,4.39 \pm 1.41)$. Moreover, both nursing educators and students were satisfied with the output quality, however, nursing educators significantly rated it $(5.14 \pm 1.37)$ higher than nursing students $(4.52 \pm 147)$ (see Table 2).

\subsection{Factors affecting the perception of institutional qual- ity at the Faculty of Nursing, Alexandria University}

To answer the second research question, the present study examined some factors in relation to the perception of institutional quality, including nursing educators' academic department, position, participation in quality improvement projects and related activities and students' semester. Regarding the academic department, the present study revealed significant differences among nursing educators across academic departments regarding their perception of overall institutional quality $(f=2.161, p=.032)$ as well as process $(f=3.283, p=$ $.001)$, and output dimensions $(f=2.506, p=.013)$. Nursing educators in the Gerontological nursing department had the highest mean of institutional quality and its dimensions (5.83 $\pm 0.69)$. While, nursing educators in the Nursing Education department had the lowest mean of overall institutional quality and its dimensions $(4.25 \pm 1.11)$ (see Table 3 ).

In relation to academic position, significant differences were found among nursing educators at different academic positions regarding their perception of overall institutional quality $(f=5.203, p \leq .001)$. Professors had the highest rating of overall institutional quality $(5.47 \pm 0.77)$, as well as input $(5.27 \pm 0.88)$, process $(6.02 \pm 0.71)$, and output dimensions $(6.09 \pm 0.68)$. While, demonstrators had the lowest rating of overall institutional quality $(4.57 \pm 0.91)$, as well as input $(4.44 \pm 0.93)$, and process dimensions $(5.10 \pm 1.05)$. In addition, clinical instructors had the lowest mean rating of the output dimension of institutional quality $(4.57 \pm 1.49)$ (see Table 4). 
Table 1. Demographic characteristics of nursing educators and students at the Faculty of Nursing, Alexandria University

\begin{tabular}{|c|c|c|}
\hline Demographic Characteristics of study participants & $\begin{array}{l}\text { Nursing Educators }(\mathrm{N}=230) \\
\text { n }(\%)\end{array}$ & $\begin{array}{l}\text { Nursing Students }(\mathrm{N}=450) \\
\mathrm{n}(\%)\end{array}$ \\
\hline \multicolumn{3}{|l|}{ Sex } \\
\hline Female & $223(97)$ & $332(73.8)$ \\
\hline Male & $7(3)$ & $118(26.2)$ \\
\hline $\begin{array}{l}\text { Age } \\
20-30\end{array}$ & $95(41.3)$ & \multirow{5}{*}{$\begin{array}{l}\text { Min.-Max (18.0-26.0) } \\
\text { Mean } \pm \text { SD (20.36 } \pm 1.27)\end{array}$} \\
\hline $31-40$ & $58(25.2)$ & \\
\hline $41-50$ & $29(12.6)$ & \\
\hline $51-60$ & $27(11.7)$ & \\
\hline \multirow{3}{*}{$>60$} & $21(9.1)$ & \\
\hline & & 1st semester $50(11.1)$ \\
\hline & & 2nd semester $60(13.3)$ \\
\hline Education level & & 3rd semester $\quad 60(13.3)$ \\
\hline Doctorate & $111(48.3)$ & 4th semester $41(9.1)$ \\
\hline Masters & $40(17.4)$ & 5th semester $56(12.4)$ \\
\hline \multirow[t]{3}{*}{ Bachelors } & $79(34.3)$ & 6th semester $27(6.0)$ \\
\hline & & 7th semester \\
\hline & & 8th semester 76 (16.9) \\
\hline \multicolumn{3}{|l|}{ Current academic position } \\
\hline Professor & $44(19.1)$ & \multirow{6}{*}{-} \\
\hline Assistant professor & $19(8.3)$ & \\
\hline Lecturer & $46(20.0)$ & \\
\hline Assistant lecturer & $34(14.8)$ & \\
\hline Demonstrator & $44(19.1)$ & \\
\hline Clinical instructor & $43(18.7)$ & \\
\hline \multicolumn{3}{|l|}{ Academic nursing department } \\
\hline Medical-Surgical & $67(29.1)$ & \\
\hline Critical care and Emergency & $15(6.5)$ & \\
\hline Obstetric and Gynecology & $25(10.9)$ & \\
\hline Pediatric & $21(9.1)$ & \\
\hline Psychiatric and mental health & $12(5.2)$ & \\
\hline Community health & $34(14.8)$ & \\
\hline Gerontological & $22(9.6)$ & \\
\hline Nursing Administration & $17(7.4)$ & \\
\hline Nursing Education & $17(7.4)$ & \\
\hline \multicolumn{2}{|l|}{ Years of experience } & \multirow{6}{*}{-} \\
\hline$<5$ & $61(26.5)$ & \\
\hline $5-10$ & $53(23.0)$ & \\
\hline $11-15$ & $28(12.2)$ & \\
\hline $16-20$ & $22(9.6)$ & \\
\hline$>20$ & 66 (28.7) & \\
\hline \multicolumn{3}{|l|}{$\begin{array}{l}\text { Nursing educators' participation in faculty quality } \\
\text { improvement projects and related activities }\end{array}$} \\
\hline Yes & $132(57.4)$ & \multirow[t]{2}{*}{ - } \\
\hline No & $98(42.6)$ & \\
\hline
\end{tabular}


Table 2. Nursing educators' and nursing students' perception of the institutional quality at Faculty of Nursing, Alexandria University

\begin{tabular}{|c|c|c|c|c|}
\hline \multirow{2}{*}{ Dimensions of institutional quality and related factors } & Nursing Educators & Nursing Students & \multirow{2}{*}{$t$} & \multirow{2}{*}{$p$} \\
\hline & Mean \pm SD & Mean \pm SD & & \\
\hline Overall Institutional Quality & $4.97 \pm 0.93$ & $4.25 \pm 1.14$ & 8.460 & $<.001^{*}$ \\
\hline Input dimension & $4.79 \pm 0.97$ & $4.13 \pm 1.16$ & 7.856 & $<.001^{*}$ \\
\hline 1) Faculty mission and purpose & $5.47 \pm 1.17$ & $4.36 \pm 1.44$ & 10.757 & $<.001^{*}$ \\
\hline 2) The excellence of facilities and resources & $4.63 \pm 1.28$ & $4.50 \pm 1.32$ & 1.218 & .224 \\
\hline 3) Faculty Teaching staff & $5.09 \pm 1.07$ & $4.24 \pm 1.35$ & 8.862 & $<.001 *$ \\
\hline 4) Instruction material efficiency & $4.92 \pm 1.11$ & $4.20 \pm 1.28$ & 7.456 & $<.001^{*}$ \\
\hline 5) Student service-governance and administration & $4.57 \pm 1.08$ & $3.70 \pm 1.30$ & 9.328 & $<.001^{*}$ \\
\hline 6) Financial resources & $4.34 \pm 1.27$ & $3.96 \pm 1.35$ & 3.541 & $<.001^{*}$ \\
\hline 7) Institutional reputation & $4.88 \pm 1.11$ & $4.22 \pm 1.44$ & 6.582 & $<.001^{*}$ \\
\hline 8) Faculty climate & $4.60 \pm 1.28$ & $3.86 \pm 1.51$ & 6.713 & $<.001^{*}$ \\
\hline Process dimension & $5.50 \pm 0.98$ & $4.64 \pm 1.34$ & 9.535 & $<.001^{*}$ \\
\hline Job expectations & $5.79 \pm 1.0$ & $4.98 \pm 1.49$ & 8.292 & $<.001^{*}$ \\
\hline Academic development & $5.30 \pm 1.11$ & $4.39 \pm 1.41$ & 9.139 & $<.001^{*}$ \\
\hline Output dimension & $5.14 \pm 1.37$ & $4.52 \pm 1.47$ & 5.356 & $<.001^{*}$ \\
\hline Overall satisfaction with the faculty quality & $5.14 \pm 1.37$ & $4.52 \pm 1.47$ & 5.356 & $<.001 *$ \\
\hline
\end{tabular}

Note. SD: Standard Deviation; $t$ : Student $t$-test; *: Statistically significant at $p \leq .05$.

Table 3. Perception of institutional quality according to nursing educators' academic department

\begin{tabular}{lllll}
\hline $\begin{array}{l}\text { Academic nursing } \\
\text { department }\end{array}$ & $\begin{array}{l}\text { Overall Institutional quality } \\
\text { Mean } \pm \text { SD }\end{array}$ & $\begin{array}{l}\text { Input dimension } \\
\text { Mean } \pm \text { SD }\end{array}$ & $\begin{array}{l}\text { Process dimension } \\
\text { Mean } \pm \text { SD }\end{array}$ & $\begin{array}{l}\text { Output dimension } \\
\text { Mean } \pm \text { SD }\end{array}$ \\
\hline Medical-Surgical & $4.99 \pm 0.94$ & $4.80 \pm 1.02$ & $5.61 \pm 0.89$ & $5.41 \pm 1.15$ \\
Critical care and Emergency & $5.04 \pm 1.01$ & $4.80 \pm 0.96$ & $5.83 \pm 1.21$ & $5.52 \pm 1.48$ \\
Obstetric and Gynecology & $4.78 \pm 1.02$ & $4.67 \pm 1.04$ & $5.32 \pm 0.99$ & $4.65 \pm 1.64$ \\
Pediatric & $5.13 \pm 0.71$ & $5.02 \pm 0.75$ & $5.55 \pm 0.63$ & $5.28 \pm 1.08$ \\
Psychiatric and mental health & $5.0 \pm 0.67$ & $4.79 \pm 0.55$ & $5.78 \pm 1.11$ & $5.25 \pm 1.41$ \\
Community health & $4.91 \pm 0.91$ & $4.79 \pm 0.97$ & $5.51 \pm 0.79$ & $4.76 \pm 1.55$ \\
Gerontological & $5.38 \pm 0.69$ & $5.22 \pm 0.80$ & $5.91 \pm 0.66$ & $5.69 \pm 0.89$ \\
Nursing Administration & $4.82 \pm 0.93$ & $4.74 \pm 0.96$ & $5.09 \pm 1.07$ & $5.05 \pm 1.44$ \\
Nursing Education & $4.25 \pm 1.11$ & $4.15 \pm 1.11$ & $4.64 \pm 1.38$ & $4.36 \pm 1.52$ \\
F (p) & $\mathbf{2 . 1 6 1}(\mathbf{. 0 3 2})$ & $\mathbf{1 . 7 1 9} \mathbf{( . 0 9 5 )}$ & $\mathbf{3 . 2 8 3}(\mathbf{. 0 0 1 * )}$ & $\mathbf{2 . 5 0 6}(\mathbf{. 0 1 3 * )}$ \\
\hline
\end{tabular}

Note. SD: Standard Deviation; F: f test (ANOVA); *: Statistically significant at $p \leq .05$.

Table 4. Perception of institutional quality according to nursing educators' current academic position

\begin{tabular}{lllll}
\hline Current academic Position & $\begin{array}{l}\text { Overall institutional quality } \\
\text { Mean } \pm \text { SD }\end{array}$ & $\begin{array}{l}\text { Input dimension } \\
\text { Mean } \pm \text { SD }\end{array}$ & $\begin{array}{l}\text { Process dimension } \\
\text { Mean } \pm \text { SD }\end{array}$ & $\begin{array}{l}\text { Output dimension } \\
\text { Mean } \pm \text { SD }\end{array}$ \\
\hline Professor & $5.47 \pm 0.77$ & $5.27 \pm 0.88$ & $6.02 \pm 0.71$ & $6.09 \pm 0.68$ \\
Assistant professor & $5.18 \pm 0.93$ & $5.03 \pm 0.97$ & $5.73 \pm 0.87$ & $5.43 \pm 1.39$ \\
Lecturer & $4.84 \pm 1.08$ & $4.67 \pm 1.10$ & $5.46 \pm 1.15$ & $5.08 \pm 1.38$ \\
Assistant lecturer & $4.89 \pm 0.61$ & $4.66 \pm 0.70$ & $5.72 \pm 0.56$ & $5.27 \pm 1.16$ \\
Demonstrator & $4.57 \pm 0.91$ & $4.44 \pm 0.93$ & $5.10 \pm 1.05$ & $4.60 \pm 1.38$ \\
Clinical instructor & $4.84 \pm 0.92$ & $4.80 \pm 0.96$ & $5.16 \pm 0.99$ & $4.57 \pm 1.49$ \\
F (p) & $\mathbf{5 . 2 0 3 ( < . 0 0 1 * )}$ & $\mathbf{4 . 0 3 7 ( . 0 0 2 * )}$ & $\mathbf{6 . 0 8 5}(\mathbf{. 0 0 1} *)$ & $\mathbf{8 . 5 1 3 ( < . 0 0 1 * )}$ \\
\hline
\end{tabular}

Note. SD: Standard Deviation; F: f test (ANOVA); *: Statistically significant at $p \leq .05$. 
Table 5 showed significant differences between nursing ed- $=.047)$ and process factors $(t=2.663, p=.008)$. Nursing ucators who participated in quality improvement projects and related activities and who did not participate regarding educators who participated in quality improvement projects their perception of overall institutional quality $(t=1.999, p$ and related activities had the highest rating of institutional quality and its dimensions $(5.05 \pm 0.89)$.

Table 5. Perception of institutional quality according to nursing educators' participation in faculty quality improvement projects and related activities

\begin{tabular}{lllll}
\hline $\begin{array}{l}\text { Participation in quality improvement } \\
\text { projects and related activities }\end{array}$ & $\begin{array}{l}\text { Overall institutional } \\
\text { quality } \\
\text { Mean } \pm \text { SD }\end{array}$ & $\begin{array}{l}\text { Input dimension } \\
\text { Mean } \pm \text { SD }\end{array}$ & $\begin{array}{l}\text { Process } \\
\text { dimension } \\
\text { Mean } \pm \text { SD }\end{array}$ & $\begin{array}{l}\text { Output } \\
\text { dimension } \\
\text { Mean } \pm \text { SD }\end{array}$ \\
\hline Yes & $5.05 \pm 0.89$ & $4.88 \pm 0.93$ & $5.65 \pm 0.93$ & $5.29 \pm 1.38$ \\
No & $4.80 \pm 0.96$ & $4.67 \pm 1.0$ & $5.30 \pm 1.01$ & $4.94 \pm 1.33$ \\
$t(p)$ & $1.999\left(.047^{*}\right)$ & $1.631(.104)$ & $2.663\left(.008^{*}\right)$ & $1.954(.051)$ \\
\hline
\end{tabular}

Note. SD: Standard Deviation; $t$ : Student $t$-test; *: Statistically significant at $p \leq .05$.

In addition, for students' current academic semester, a significant difference was found among nursing students across academic semesters regarding their perception of overall institutional quality of the faculty of nursing $(f=15.524, p \leq$ $.001)$. The same trend of the result was reflected in input $(f$ $=14.208, p=.001)$, process $(\mathrm{f}=13.089, p \leq .001)$, and output dimension of institutional quality $(f=9.981, p \leq .001)$.
Nursing students at the 2nd semester had the highest rating of overall institutional quality (5.21 \pm 0.77$)$, as well as input $(5.07 \pm 0.84)$, process $(5.72 \pm 0.81)$ and output dimension $(5.44 \pm 0.99)$. While, nursing students at 7 th semester had the lowest rating of overall institutional quality $(3.61 \pm 1.06)$ as well as input $(3.49 \pm 1.08)$, process $(4.07 \pm 1.28)$, and output dimensions $(3.81 \pm 1.46)$ (see Table 6).

Table 6. Perception of institutional quality according to students' current academic semester

\begin{tabular}{lllll}
\hline $\begin{array}{l}\text { Current academic } \\
\text { semester }\end{array}$ & $\begin{array}{l}\text { Overall institutional quality } \\
\text { Mean } \pm \text { SD }\end{array}$ & $\begin{array}{l}\text { Input dimension } \\
\text { Mean } \pm \text { SD }\end{array}$ & $\begin{array}{l}\text { Process dimension } \\
\text { Mean } \pm \text { SD }\end{array}$ & $\begin{array}{l}\text { Output dimension } \\
\text { Mean } \pm \text { SD }\end{array}$ \\
\hline First & $4.84 \pm 0.75$ & $4.68 \pm 0.76$ & $5.28 \pm 0.98$ & $5.27 \pm 0.98$ \\
Second & $5.21 \pm 0.77$ & $5.07 \pm 0.84$ & $5.72 \pm 0.81$ & $5.44 \pm 0.99$ \\
Third & $4.21 \pm 1.13$ & $4.07 \pm 1.13$ & $4.64 \pm 1.16$ & $4.54 \pm 1.59$ \\
Fourth & $4.24 \pm 0.99$ & $4.15 \pm 0.90$ & $4.61 \pm 1.37$ & $4.35 \pm 1.55$ \\
Fifth & $4.01 \pm 1.15$ & $3.95 \pm 1.18$ & $4.31 \pm 1.37$ & $4.12 \pm 1.44$ \\
Sixth & $4.40 \pm 0.94$ & $4.29 \pm 1.0$ & $4.75 \pm 1.06$ & $4.66 \pm 1.18$ \\
Seventh & $3.61 \pm 1.06$ & $3.49 \pm 1.08$ & $4.07 \pm 1.28$ & $3.81 \pm 1.46$ \\
Eighth & $3.94 \pm 1.21$ & $3.83 \pm 1.25$ & $4.18 \pm 1.49$ & $4.36 \pm 1.50$ \\
F (p) & $\mathbf{1 5 . 5 2 4}(<.001 *)$ & $\mathbf{1 4 . 2 0 8 ( < . 0 0 1 * )}$ & $\mathbf{1 3 . 0 8 9 ( < . 0 0 1 * )}$ & $\mathbf{9 . 9 8 1}(<.001 *)$ \\
\hline
\end{tabular}

Note. SD: Standard Deviation; F: f test (ANOVA); *: Statistically significant at $p \leq .05$.

\section{Discussion}

Quality teaching is considered as a distinctive feature contributing to the overall quality of the institution, along with scientific reputation and the quality of the learning environment. The results of the current study with the primary aim to investigate the perception of nursing educators and nursing students regarding institutional quality could offer a useful feedback to administrators in their efforts to improve service quality in the Faculty of Nursing, Alexandria University.

The present study revealed that although both nursing educators and students rated the institutional quality of the Fac-

Published by Sciedu Press ulty of Nursing as moderate, nursing educators significantly rated and perceived institutional quality and its dimensions higher than students. The difference in perception could be explained in the light of extended experience of nursing educators that provide them with the insight, awareness, and information about quality services at the faculty and the ability to evaluate their quality system precisely more than nursing students. Also, this finding supports the notion that different consumers have different perspectives of quality and different needs and expectations.

This speculation could be supported by Vann (2012) and 
Tang \& Hussin (2011) who stated that, different stakeholder groups held different perceptions of the quality in higher education. $^{[8,16]}$ Also, Lodesso (2012) showed that, the staff and students' perceptions-expectations gap/discrepancy on service quality differed significant statistically. ${ }^{[17]}$ Moreover, Richardson (2003) found varying perceptions by administrators, teachers, and professional staff members regarding local school improvement efforts resulting from the last accreditation visits. ${ }^{[18]}$

The perception of current institutional quality was consistent with Chua (2004) who found that faculty members perceived quality as relating to the whole education system. They believed that the education system should focus on all aspects of their activities (i.e. Input, process and output). ${ }^{[19]}$ In this regard, Amaral (2002) suggested that, institutions must get external stakeholders' opinions on program development, as saw from program accreditation rules. ${ }^{[20]}$

Specifically, input factors that strengthen nursing educators and students' perception of institutional quality were "faculty mission and purpose, faculty teaching staff and excellence of facilities and resources". In fact, Faculty of Nursing, Alexandria University has a clearly stated vision and mission, which formulated by members of the curriculum committee, administrators, staff members, and stakeholders and published in all departments to be informed for all staff members and students who periodically involved in their revision and updating. In addition, the faculty had a qualified staff members who were committed to quality and had ability to achieve its mission and strategic objectives in relation to the educational program, research and community services.

Moreover, during and after accreditation process, the faculty became supplied more with adequate facilities and resources to improve the educational process such as classrooms, libraries, internet services, smart boards, information technology center, and computer lab besides nine well equipped clinical skills labs for developing nursing skills related to basic training of students which facilitate the learning process. All of these factors could enhance the perception and satisfaction with institutional quality.

This result go in the same line with Vann (2012) who clarified that teachers believed, a good quality university should have good resources and qualified teachers who have research skills, relevant curriculum, adequate learning and teaching resources, good delivery of courses and content, adequate funds to cover expenses and pay the teachers' salaries, and good governance and a good leader with academic background. ${ }^{[8]}$ A similar result was found by, Kimani, Kagira, \& Kendi (2011) who indicated that, students perceived their university provided them with adequate learning facilities and equipment, in addition to health services, recreational facilities and excellent counseling services. ${ }^{[21]}$ On the contrary, the finding of the present study is inconsistent with Winsted (2000) who reported students' dissatisfaction with facilities and resources of the faculty. ${ }^{[22]}$ In this context, Watty (2005) revealed that, academics define quality in higher education in terms of the transfer of knowledge, good academic training and teaching, a good learning environment, research and a good quality assurance mechanism. ${ }^{[23]}$

On the other hand, "financial resources" was rated as the lowest input factor by nursing educators and, "student servicegovernance and administration" was rated as the lowest by nursing students. This finding may be resulting from the non involvement of all staff members in the financial issues of the faculty in turn, the non awareness of the actual expenses and budget control. Also, some students complained of dealing with the student affairs office, with administrative staff members, difficult to use faculty facilities and waited to receive administrative services. Most of the nursing students had less frequent contact with the employees of the student affairs office because they depend on their students' representatives who had more contact with administrative staff. This result could be supported by the conclusion of the meeting of the Complaints' Committee and proposals at the Faculty of Nursing, which conducted every 15 days regularly to examine the complaints of its customers.

In the same line, Harris (2002) confirmed that, students were dissatisfied with the administrative service quality. ${ }^{[24]}$ On the contrary, Kimani, Kagira, \& Kendi (2011) found that students perceived administrative staff as; kept their promises, had positive attitude towards them, communicated well with them, dealt with their inquiries/complaints efficiently and promptly. In addition that the staff has been always courteous and polite. ${ }^{[21]}$ In this respect, White (2000) highlighted that, frequent contact with faculty members lead to students' retention and satisfaction in educational institutions. ${ }^{[25]}$ In addition, Pearson \& Chatterjee (2004) reported that permanent relationship with faculty and employees could lead to greater students' satisfaction. ${ }^{[26]}$

Regarding process dimension, both nursing educators and students rated job expectations higher than academic development. In addition, both of them were satisfied with output quality as a result of the interaction of factors that comprised the input and process dimensions. Nursing educators might perceive that identifying and meeting their job expectations is the most important factor in enhancing the process of institutional quality. In fact, the faculty has a good reputation as evidenced by the comments of stakeholders in different meeting and conferences. Nursing students perceived that the 
faculty support them with work study and curricula needed for life and offer employment chances for them after graduation especially after the accreditation process of the faculty. Nursing students reported that they feel proud with faculty choice and perceived that the faculty is a stepping - to their scientific and working life.

Similarly, Chua (2004) found, that faculty was concerned with reputation and employability. ${ }^{[19]}$ Also, Kimani, Kagira, \& Kendi (2011) found general agreement among students that universities supported them with work study when needed and offered employment to their graduates. ${ }^{[21]}$ In addition, Bindsardi \& Ekwulugo (2003), and Ho \& Hung (2008) indicated that the public focus on the process and output rather than input of the education system when they evaluate the quality of an education program. They consider the reputation as credibility and trust of the program which is created by practical curriculum that delivered by competent faculty and the track record of past and students getting good employment as important. ${ }^{[27,28]}$

Regarding factors affecting the perception of institutional quality, significant differences were found among nursing educators across different academic departments regarding their perception of overall institutional quality and its dimensions. Several factors could lead to these differences in perception. In fact, the success of quality initiatives supported by the faculty depends mainly on the commitment of the heads of departments who promote the teaching and team spirit and allow operational implementation of quality issues and activities. In addition to the availability and quality of staff members. Head of Gerontological nursing department might apply motivational strategies and encourage faculty members and notify them with everything related to the quality issue (this result identified from asking some of nursing educators at this department). In contrast, a few teaching staff in the department to participate in quality activities, lack of interest in quality issue and activities and staff who complained from workload and no enough time to participate in quality activities in addition to new faculty members who didn't have enough information related to quality as in the Nursing Education department could lessen the perception of institutional quality.

This result could be supported by the findings from (Questionnaire to measure the awareness of the faculty members and assistants for quality support systems, distributed in 2012 from Quality Assurance Unit) which illustrated that, there were significant differences among nursing educators in different academic departments regarding their awareness of the quality system at the faculty. Also, Rowland (2008) stated that, heavy workload was considered a burden and influenced nurse educators' job satisfaction and quality perception. ${ }^{[29]}$ In this regard, Bhate (2013) stated that, supervisors/ leaders act as effective mediators and "primary implementers of work policies initiated by various organizations". Given the prominence of work/family issues among employees today, having a supportive supervisor is a characteristic of effective friendly workplaces. ${ }^{[30]}$ Only through good relationships combined with strong, sensitive leadership, a cohesive department can be built.

Moreover, the current study revealed that the perception of the institutional quality was affected also, by the increased level of education, and higher academic position as well as the participation in the quality improvement project and related activities. These results could be justified in the light of increased age, years of experience and educational levels of nursing educators which might give them the opportunity and responsibility to be involved in quality improvement activities, had more knowledge and sense of confidence and competence about quality activities and culture, so they had a positive perception of institutional quality. Professors could naturally assume an active role model by creating an environment conductive to the growth and advancement than less experienced educators.

Similarly, Bigne, Moliner, \& Sanchez (2003) clarified that, the higher aged faculty members who had been with the organization longer and in higher position scored higher level of satisfaction with the organization than the youngest. ${ }^{[31]}$ Also, Palacio, Meneses, \& Perez (2012) found older faculty members as more skillful and experienced and had increased knowledge that helped them to improve quality in educational institutions. ${ }^{[32]}$ In the same line, Kettunen \& Kantola (2007) reported that, the more participation in quality activities, the more satisfaction with organizational quality. ${ }^{[33]}$ In addition, Kehm (2010) found that, the most critical variables affecting institutional quality were information about the institution and participating in the accreditation process. ${ }^{[34]}$

In contrast, O'Neill \& Palmer (2004) mentioned that, there was no statistically significant difference between perceptions of faculty members of the institutional quality and their age. ${ }^{[35]}$ Also, Yeo (2008) reported that level of education had a negative relationship with institutional quality. ${ }^{[36]}$ In light of this finding, most of nursing educators out of all respondents in the current study suggested to develop strategy for involving all staff members as possible to share in all quality improvement activities to raise the faculty interest in quality issue in turn, improving the teaching - learning process.

Finally, the finding of the present study revealed significant differences among nursing students across different academic semesters regarding their perception of overall institutional 
quality and its dimensions. This result could be ascribed to the differences in the students' concerns and the information about quality services rendered at the faculty. Students in the first academic year were more concerned with identifying the new university context and life. They challenged to know what services provided in the faculty and assume their identity as university students. Many of them participated in different social, community and academic activities. While, the majority of students in the last academic year, became more focused on their graduation from the faculty and did not care to know any change in the institutional system. They may have not received adequate incentives from the quality projects, and become not interested in quality issues. This result is consistent with Uche (2012) who concluded that the mean scores for the final year students were lower than those of the first year students who were not interested in university quality. ${ }^{[37]}$ Also, Oldfield \& Baron (2000) reported that perception of service quality elements changed over a period of academic study. ${ }^{[10]}$

\section{Conclusion}

In sum, positive institutional quality related to a positive perception of both nursing educators and students of institutional quality. It can be concluded that both nursing educators and students, moderately satisfied with institutional quality of the Faculty of Nursing, Alexandria University. However, nursing educators significantly perceived overall institutional quality and its dimensions higher than students. "Faculty mission and purpose, teaching staff quality and excellence of facilities and resources and job expectations and output quality" were the most prominent factors of institutional quality that strengthen nursing educators and students' perception. While, "financial resources and student service-governance and administration" were the least perceived factors of institutional quality. In addition, perception of institutional quality also, affected by factors such as the academic department, position, semester and participation in quality improvement projects and related activities.

\section{Study strengths \& limitations}

The current research provides a conceptual model, and a standardized measure for measuring quality of higher education institutions specifically in nursing literature. Although perceptions of consumers such as nursing educators and students are important, institutional quality is more than what they percieve especially in a program like nursing. This study could be a preliminary step for further researches. Also, the sample was from one setting and the result cannot be generalized. Replication of the study is required.

\section{RECOMMENDATIONS}

The current study recommended that, different strategies should be implemented by administrators and leaders of the Faculty of Nursing to continue improvement of institutional quality through; enhancing a quality teaching framework which allows the institution to monitor, support, track nursing educators' and students' satisfaction, and study its impact on the learning process. In addition, strategies to upgrade the qualification and skills of teaching staff are recommended. Such as, providing opportunities to attend conferences, scientific meetings, continuous training programs, and workshops related to quality issues are required to enhance the importance of the quality system in the faculty especially to whom younger with fewer years of experience. In addition, providing strong and sensitive leadership and administrative-service support from faculty's leaders for both nursing educators and students are important to enhance team spirit and increase their commitment to the faculty quality and students' feeling of a supportive learning environment.

\section{Future research implications}

To address some of the shortcomings of the present study, future researches should be conducted to: compare between the perception of internal and external consumers of quality in accredited and non-accredited higher institutions; examine other factors which considered significant in determining institutional quality such as hiring rates, and stakeholders and employers' satisfaction with graduates. Replication of study in a wider context could help with the provision of a comprehensive picture and perception of the institutional quality in higher education.

\section{ACKNOWLEDGEMENTS}

We would like to thank all participants who agreed to participate in this research study.

\section{Conflicts OF InTEREST Disclosure}

The Authors declare that there is no conflict of interest.

\section{REFERENCES}

[1] Gilbert G, Parhizgari A. Organizational effectiveness indicators to support service quality. Managing Service Quality. 1999; 10(1): 46-
51. http://dx.doi.org/10.1108/09604520010307030

[2] Yilmaz H, Demircan V, Bal T, et al. Students' perceptions of academic and institutional service quality. Turkey: Suleyman Demirel 
University. 2010.

[3] Gencel U. Total quality management and accreditation in higher education service. Dokuz Eylul University. Quality Quest in the Academic process. 2001; 3(3): 164-218.

[4] Quality Assurance Agency for Higher Education (QAAHE): QAA External Review Process for Higher Education in England: Operation Description. 2002. Available from: http://www. oecd.org/dat aoecd/52/23/44058352.pdf

[5] Pavel A. The importance of quality in higher education in an increasingly knowledge-driven society. International Journal of Academic Research in Accounting, Finance and Management Sciences. 2012; 2(1): 120-127.

[6] Yoo G. An adaptation of university students' perception of institutional quality. Published Doctoral Dissertation. Germany: University of Pittsburgh; 2001.

[7] Santiago P, Tremblay K, Basri E, et al. OECD. Introduction. Tertiary Education For The Knowledge Society. 2008; 1: 23-28.

[8] Vann M. Stakeholder's perceptions of quality in Cambodian Higher education. Published Doctoral Dissertation. School of Global Studies, Social Science and Planning Design and Social Context Portfolio RMIT University; 2012.

[9] Kiran K. Service quality and consumer satisfaction in academic libraries: Perspectives from a Malaysian University. Library Review. 2010; 59(4): 261-273. http://dx.doi.org/10.1108/0024253 1011038578

[10] Oldfield B, Baron S. Student's perception of service quality in a UK University, Business and Management Faculty. Quality Assurance in Education. 2000; 8(2): 85-95. http://dx.doi.org/10.1108 109684880010325600

[11] Abouchedid K, Nasser R. Assuring quality service in higher education: Registration and advising attitudes University in Lebanon. Quality Assurance in Education. 2002; 10(4): 198-206. http: //dx.doi.org/10.1108/09684880210446866

[12] Black H, Duhon D. Evaluating and improving student achievement in business programs: The effective use of standardized assessment tests. Journal of Education for Business. 2003; 79(2): 90-98. http://dx.doi.org/10.1080/08832320309599095

[13] Mohammad S, Owlia M. A framework for the dimensions of quality in higher education. Quality Assurance in Education. 1996; 4(2): 12-20. http://dx.doi.org/10.1108/09684889610116012

[14] Tamer A, Ragab A, Metwally A. Students' satisfaction at educational institutions and recommending it to potential students. The 1st Annual International Conference for Global Integration of Graduate Programs GIGP, Kiev. International Journal of Islamic and Middle Eastern Finance \& Management. 2003. Available from: http://www.lifesciencesite.com/lsj/life0804

[15] Faculty of nursing, Alexandria University: Mission and Vision. 2012. Available from: http://www . alexnursing.edu.eg/

[16] Tang S, Hussin S. Quality in higher education: A variety of stakeholder perspectives. International Journal of Social Science and Humanity. 2011; 1 (2): 126-131. http://dx.doi.org/10.7763/I JSSH. 2011.V1.21

[17] Lodesso S. Stakeholder perceptions of service quality improvement in Ethiopian public higher education institutions. 2012. Available from: http://uir.unisa.ac.za/handle/10500/9484

[18] Richardson J. Examining social presence in online courses in relation to students perceived learning and satisfaction. Journal of Asynchronous Learning NT. 2003; 7(1): 68-88.

[19] Chua C. Perception of quality in higher education. Proceeding of the Australian University Forum. 2004. Available from: https://citeseerx.ist.psu.edu/viewdoc/download ?doi\%3D10.1.1.125.3578
[20] Amaral A. Governing Higher Education: National perspectives on institutional governance. The emergent role of external stakeholders in European Higher Education Governance. 2002. Available from: http://www.emeraldinsight.com/doi/full/10 .1108/08876040210433248

[21] Kimani S, Kagira E, Kendi L. Comparative Analysis of Business Students' Perceptions of Service Quality Offered in Kenyan Universities. International Journal of Business Administration. 2011; 2(1): 98-112. http://dx.doi.org/10.5430/jms.v3n1p55

[22] Winsted F. Service behaviors that lead to satisfied customers. European Journal of Marketing. 2000; 34 (4): 399-417. http://dx. doi .org/10.1108/03090560010311920

[23] Watty K. Quality in accounting education: What say the academics. Quality Assurance in Education. 2005; 13(2): 120-131. http://dx.doi.org/10.1108/09684880510594373

[24] Harris B. A study of service quality: Gap analysis of expectations versus performance perceptions of junior, senior, and graduate students. Published dissertation, University of Alabama; 2002.

[25] White E. Student satisfaction for academic performance. Published Master Thesis. University of Massachusetts. Lincoln; 2000.

[26] Pearson C, Chatterjee R. Expectations and values of university students in transition: Evidence from an Australian classroom. Management Education. 2004; 24(4): 427-446. http://dx.doi.org/10. $1177 / 1052562904266005$

[27] Bindsardi A, Ekwulugo F. International marketing of British education: Research on the students' perception and the UK market penetration. Marketing Intelligence and Planning. 2003; 21(5): 318327. http://dx.doi.org/10.1108/02634500310490265

[28] Ho H, Hung C. Marketing mix formulation for higher education: An integrated analysis employing analytic hierarchy process, cluster analysis and correspondence analysis. International Journal of Educational Management. 2008; 22(4): 328-340. http://dx.doi.org $/ 10.1108 / 09513540810875662$

[29] Rowland A. The relationship of principal leadership and teacher morale. Published Dissertations. Liberty University; Virginia: 2008.

[30] Bhate R. Supervisor supportiveness: Global Perspectives. Quick insights. 2013. Available from: https://www.bc.edu/content /dam/files/research_sites/agingandwork/pdf/publica tions/QI3_SupervisorSupport.pdf

[31] Bigne E, Moliner A, Sanchez J. Perceived quality and satisfaction in multi service organizations: The case of Spanish public services. The Journal of Services Marketing. 2003; 17(4): 420-442. http://dx.doi.org/10.1108/08876040310482801

[32] Palacio B, Meneses D, Perez P. The configuration of the university image and its relationship with the satisfaction of students. Journal of Educational Administration. 2012; 40(5): 486-505. http: //dx.doi.org/10.1108/09578230210440311

[33] Kettunen J, Kantola M. Strategic planning and quality assurance in the Bologna Process. Perspective. 2007; 11(3): 67-73.

[34] Kehm M. Quality in European Higher Education: The influence of the Bologna Process. 2010

[35] O'Neill A, Palmer A. Importance-performance analysis: a useful tool for directing continuous quality improvement in higher education. Quality Assurance in Education. 2004; 12(1): 39-52. http://dx.doi.org/10.1108/09684880410517423

[36] Yeo K. Brewing service quality in higher education. Quality Assurance in Education. 2008; 16(3): 266-286. http://dx. doi .org/1 $0.1108 / 09684880810886277$

[37] Uche C. Students' perception of academic staff quality: A measure of quality assurance in South-South Nigerian Higher Institutions. International Journal of Educational Science. 2012; 4(2): 163-173. 